Article

\title{
Extruded Linseed and Oregano Dietary Supplementation: Effects on Growth Performance, Carcass Composition, and Meat Quality of Jonica Kids
}

\author{
Felice Vizzielli ${ }^{1}$, Simona Tarricone ${ }^{2, *} \mathbb{C}$, Salvatore Claps ${ }^{3}$, Giuseppe De Mastro ${ }^{2}(\mathbb{D})$ and Marco Ragni ${ }^{2}$ \\ 1 Lucanian Agency of Development and Innovation Agriculture (ALSIA), 75100 Matera, Italy; \\ felice.vizzielli@alsia.it \\ 2 Department of Agricultural and Environmental Science, University of Bari, Aldo Moro, 70125 Bari, Italy; \\ giuseppe.demastro@uniba.it (G.D.M.); marco.ragni@uniba.it (M.R.) \\ 3 Council for Agricultural Research and Economics, Research Centre for Animal Production and Aquaculture, \\ 85051 Bella Muro, Italy; salvatore.claps@crea.gov.it \\ * Correspondence: simona.tarricone@uniba.it
}

check for updates

Citation: Vizzielli, F.; Tarricone, S.; Claps, S.; De Mastro, G.; Ragni, M. Extruded Linseed and Oregano

Dietary Supplementation: Effects on Growth Performance, Carcass Composition, and Meat Quality of Jonica Kids. Ruminants 2021, 1 , 127-136. https://doi.org/10.3390/ ruminants 1020010

Academic Editor: Ulrich Meyer

Received: 25 June 2021

Accepted: 15 October 2021

Published: 20 October 2021

Publisher's Note: MDPI stays neutral with regard to jurisdictional claims in published maps and institutional affiliations.

Copyright: (c) 2021 by the authors. Licensee MDPI, Basel, Switzerland. This article is an open access article distributed under the terms and conditions of the Creative Commons Attribution (CC BY) license (https:// creativecommons.org/licenses/by/ $4.0 /)$.

\begin{abstract}
To evaluate the influence of linseed and oregano dietary supplementation in Jonica kids, we carried out a trial that involved 30 male Jonica kids 20 days old, divided into three groups of ten animals. Each group was ascribed to one of the following dietary treatments: (C) group control fed without any supplement; (L) group fed control feed containing 3\% extruded linseed (Linum usitatissimum); and ( $\mathrm{L}+\mathrm{O}$ ) group fed control diet with $0.6 \%$ dried oregano (Origanum vulgare) and $3 \%$ extruded linseed. The kids were slaughtered at 60 days of age; carcass and cut yields were performed. The Longissimus lumborum muscle was separated to determinate physical, chemical, and fatty acid composition. Supplementation of kids' diet with oregano did not show effects on performances in vivo and post mortem. Extruded linseed and oregano feed made commercial cuts of kids carcasses less fat $(6.75 \%$ vs. $10.92 \%$ for leg; $4.82 \%$ vs. $7.73 \%$ for loin), whereas only the extruded linseed diet made the meat fatter $(20.11 \%$ vs. $19.75 \%)$ and more proteic than the commercial pellet $(20.11 \%$ vs. $19.75 \%$ ). The use of oregano reduces the meat oxidation compared with the only use of linseed in kids' diet $(0.298$ vs. 0.645$)$. The healthy and beneficial effect of linseed in the diet is observed in meat with the lower value of $n-6 / n-3$ ratio (4.57 vs. 8.60$)$ and atherogenic ( 0.60 vs. 0.77$)$ and thrombogenic (1.36 vs. 1.61) indices. Linseed diet enrich kids meat with healthy fatty acids that are easier to oxidize; instead, the addition of oregano, thanks to its antioxidant properties, allows a longer conservation and a more profitable marketing.
\end{abstract}

Keywords: kids meat; performance; physical characteristics; T-BARS; fatty acid; sensory quality

\section{Introduction}

The Jonica breed is derived from a local population of the Ionian Arc area that has been repeatedly crossed with the Maltese breed. This breed has a medium to large size and has been reared and crossed in southern Italy. It is characterized by a white (sometimes pinkish) coat, with possible dark spots or patches on the head and neck. Jonica goat is suitable for milking, it can produce up to 240 litres of milk per lactation, with an average content of $3.4 \%$ fat and $3.4 \%$ protein [1], excellent for the production of traditional cheeses.

Due to improvement management of breeding and marketing strategies, the use of goats can allow the recovery of local small businesses; the typical quality products obtained (milk, cheese, meat, and meat products) today are in high demand because consumers because consumers are reducing the consumption of red meats, preferring those with greater health characteristics among these. In addition, consumers' taste in the consumption of goat meat varies greatly in Europe between the regions of northern Europe and the Mediterranean ones, which prefer younger animals [2,3]. Thanks to the actual social 
characteristic, extensive goat breeding is a type of activity can still be an economically viable and environmentally positive business choice in the era of globalization and ecommerce [1].

In Italy, the main kind of goat meat appreciated by the consumer is the "capretto". This meat has a rosy colour, with a delicate, wild taste due to kids suckling milk from goats that graze on spontaneous pastures and scrubs typical of the Mediterranean area $[4,5]$. Meat from ruminants can be considered a dietary source rich in several nutrients [6]; however, in the last several years, it has been censured for its high level of intramuscular fat, which is particularly rich in saturated fatty acid (SFA), caused by the rumen biohydrogenation of dietary fats, especially polyunsaturated fatty acid (PUFA) [7]. We assumed that the integration of linseed in feeding stuffs for small ruminants enriches meat in unsaturated fatty acids, especially omega 3 fatty acids and linolenic acid. The greater structural instability of unsaturated fatty acids, especially polyunsaturated ones, can reduce the shelf life of meat and therefore the flavour [8]. This can happen due to lipid oxidation that can be contained through the use of antioxidants. These, when properly dosed, can be included in the diet of ruminates to preserve the quality of the fatty acids present in the diet. This goal can be achieved through the use of foods naturally rich in antioxidant substances, which are included in a balanced diet can improve the quality and shelf life of meat, milk, and fresh cheeses [9]. Oregano (Origanum vulgare) is a common, natural essence presented in southern Italy pasture whose antioxidant activity is mainly attributed to carvacrol and thymol [10]; its addition in Garganica kids' diet have confirmed its effectiveness in enhancing oxidative stability in meat [11]. On the contrary, in our study on Gentile di Puglia lambs, oregano's antioxidant activity was not evident; instead, linseed and oregano are inclined to reduce the content of saturated fatty acids and to significantly improve the quantities of unsaturated and polyunsaturated fatty acids of the omega- 6 family, of the C18:3 n3, and of the total polyunsaturated fatty acids. This generate positive effects on the flavour of the meat, with a greater appreciation of the consumers.

To better understand the oregano's antioxidant activity and the effects of the combination of oregano with linseeds on ageing kids' meat, we determine the effect of dietary supplementation with oregano and extruded linseed on growth performances, carcass composition, and meat quality of Jonica kids.

\section{Materials and Methods}

\subsection{Animal Management and Diet}

All procedures involving animals have been conducted ethically and responsibly, according to the Italian government guidelines (Directive 2003/50/EC, received in Italy by D.L. 193/2005).

The study was carried out in the Research Centre for Animal Production and Aquaculture in Muro Lucano (Basilicata region, Southern Italy, latitude: $40^{\circ} 45^{\prime} 13^{\prime \prime} 64 \mathrm{~N}$, longitude: $15^{\circ} 29^{\prime} 17.1^{\prime \prime} \mathrm{E}, 650 \mathrm{~m}$ a.s.l.). It involved 30 male Jonica kids, all born as twins. Kids were reared according to the traditional farming systems for the Jonica breed, as they were exclusively milk fed from the dams until they reached the age of about 20 days, homogeneous regarding age $(20 \pm 2$ days old $)$ and initial live weight $(6.72 \pm 1.22 \mathrm{~kg})$. Each group was ascribed to one of the following dietary treatments: (C) group control fed with commercial concentrate and hay without any supplement; (L) group fed control feed containing 3\% extruded linseed (Linum usitatissimum); and $(\mathrm{L}+\mathrm{O}$ ) group fed control diet with $0.6 \%$ dried oregano (Origanum vulgare) and 3\% extruded linseed; for more details, please read our previous work [12]. Changes in feed composition did not influence the palatability of the diets; the three rations were formulated to be isocaloric and isonitrogenous and to satisfy the nutritional requirements of kids [13].

The kids were housed in individual pens $\left(0.8 \mathrm{~m}^{2} /\right.$ head) with free access to feed and water, and the temperature in pens ranged from 7 to $15^{\circ} \mathrm{C}$.

Representative samples of the pelleted feeds was evaluated to determine the chemical composition and fatty acid profile using the following "Association of Official Agricultural 
Chemistry AOAC" [14] methods; ingredients, chemicals, and fatty acids compositions were reported in our previous work [12] (Table 1).

\subsection{Growth Performance of Kids}

Every week, kids were weighed to calculate the average daily gain (ADG) until they were slaughtered at 60 days of age. After fasting for $12 \mathrm{~h}$ with free water access, kids were weighed (slaughter weight) and then slaughtered according to the official veterinary rules. Skin and hot carcass were also weighed.

As described by Scarpa et al. [12], carcasses were hung and chilled at $4{ }^{\circ} \mathrm{C}(80-82 \%$ relative humidity) for $24 \mathrm{~h}$ and then weighed to measure the cold carcass weight. On the right, Longissimus lumborum ( $\mathrm{Ll}$ ) $\mathrm{pH}$ values were measured at the time of slaughter $(\mathrm{pH} 1)$ and after $24 \mathrm{~h}(\mathrm{pH} 24)$ under refrigerated conditions $\left(4^{\circ} \mathrm{C}\right)$. After 24 hours from the slaughter, carcasses were split into two halves; the right side was divided into different commercial cuts and weighed separately to calculate their yield on the half carcass.

The meat cuts were stored at $4{ }^{\circ} \mathrm{C}$ for a further $24 \mathrm{~h}$ and then divided into tissue components (lean, dissectible fat, and bone), and the weight of each tissue was recorded [15]. Loins from the right and left carcass were transported to the laboratory under refrigerated conditions to continue other analyses.

\subsection{Physical Parameters of Longissimus Lumborum Muscle}

During the third day after slaughtering ( $3 \mathrm{~d})$, on sample of Longissimus lumborum, colour and tenderness were determined. Meat colour $\left(\mathrm{L}^{*}=\right.$ lightness, $\mathrm{a}^{*}=$ redness, $\mathrm{b}^{*}=$ yellowness) and tenderness were measured as described by Scarpa et al. [12].

Ten $\mathrm{g}$ of Longissimus lumborum muscle was used to evaluate lipid oxidation by measuring the concentration of 2-thiobarbituric acid reactive substances (T-BARS) [7] and expressed as mg malondialdehyde (MDA) $/ \mathrm{kg}$ meat.

Half part of muscle of all Longissimus lumborum was stored in meat fridge without packaging at $4{ }^{\circ} \mathrm{C}$ for a further 7 days and then analyzed again $(10 \mathrm{~d})$ for colour and texture parameters and lipid oxidation.

\subsection{Analyses of Chemical Composition and Fatty Acid of Ll Muscle}

Chemical and fatty acids composition of Longissimus lumborum muscle were determined as reported in our previous paper [12]; fatty acids were expressed as a percentage (g FA/100 g FA methyl esters) of total methylated fatty acids.

The food risk factors of meat were determined by calculating the atherogenic (AI) and thrombogenic (TI) indices [16]:

$$
\begin{array}{r}
\mathrm{AI}=[(\mathrm{C} 12: 0+4 \times \mathrm{C} 14: 0+\mathrm{C} 16: 0)] \div[\Sigma \mathrm{MUFA}+\Sigma \mathrm{n}-6+\Sigma \mathrm{n}-3] \\
\mathrm{TI}=[(\mathrm{C} 14: 0+\mathrm{C} 16: 0+\mathrm{C} 18: 0)] \div[(0.5 \times \Sigma \mathrm{MUFA}+0.5 \times \Sigma \mathrm{n}-6+3 \times \Sigma \mathrm{n}-3+\Sigma \mathrm{n}-3) / \Sigma \mathrm{n}-6]
\end{array}
$$

where MUFA are monounsaturated fatty acids; $\Sigma \mathrm{n}-6$ is the sum of C18:2 c9; t12 + $\mathrm{C} 18: 2 \mathrm{c} 9 ; \mathrm{t} 11+\mathrm{C} 18: 3+\mathrm{C} 20: 3+\mathrm{C} 20: 4) ;$ and $\Sigma \mathrm{n}-3$ is the sum of $\mathrm{C} 18: 3+\mathrm{C} 20: 3+\mathrm{C} 20: 4+\mathrm{C} 20: 5$ $+\mathrm{C} 22: 6)$.

\subsection{Statistical Analysis}

For the study, three treatments (diets) and ten replicates (kids) were analyzed with a completely randomized design. We used a GLM procedure of SAS software [17] with diet as the fixed effect:

$$
Y_{i j}=M+A_{i}+E_{i j}
$$

where $Y_{i j}=$ the response variable; $M=$ overall mean; $A_{i}=$ fixed effect of the diet; and $E_{i j}=$ residual error.

Values with significant effect by the diet $(p<0.05)$ were separated and compared by Tukey's HSD. Significance was declared at $p<0.05$; in the table, we report results (as least squares mean) and their standard error of the mean (SEM). 


\section{Results and Discussion}

\subsection{Growth Performance of Kids}

As indicated in Table 1, initial and final body weight did not show significant differences. Kids' weight at the end of the trial was similar to those shown by Rotondi [11] who studied the influence of linseed on growing Garganica kids. As in our study, Wang et al. [18] and Liu et al. [19], in their study on cashmere kids fed with linseed, did not show significant differences on growth performance after $60 \mathrm{~d}$ of trial. Supplementation of kids' diet with linseed both with and without oregano did not show effects on feed intake and feed conversion ratio. It seems that the animals fed with oregano appreciated the feed; in fact $\mathrm{L}+\mathrm{O}$ group recorded the major daily feed intake, and the same results were showed on kids [11] and on lambs [12] fed with similar diet.

Table 1. Diet effects on kids' growth performance.

\begin{tabular}{|c|c|c|c|c|c|}
\hline & \multicolumn{3}{|c|}{ Diet $^{1}$} & \multirow{2}{*}{ SEM $^{2}$} & \multirow{2}{*}{$p$-Value } \\
\hline & $\mathrm{C}$ & $\mathbf{L}$ & $\mathrm{L}+\mathrm{O}$ & & \\
\hline Initial-20 d BW ${ }^{3}(\mathrm{~kg})$ & 6.65 & 6.75 & 6.76 & 1.225 & 0.25 \\
\hline $60 \mathrm{~d}$ BW $(\mathrm{kg})$ & 11.70 & 12.28 & 12.56 & 2.211 & 0.55 \\
\hline Average daily BW gain 20-60 (kg/d) & 0.13 & 0.14 & 0.14 & 0.030 & 0.12 \\
\hline Average daily feed intake $(\mathrm{kg} / \mathrm{d})$ & 0.58 & 0.63 & 0.67 & 0.158 & 0.47 \\
\hline Feed conversion ratio & 5.23 & 5.17 & 5.68 & 0.546 & 0.52 \\
\hline
\end{tabular}

${ }^{1} \mathrm{C}$, control feed; $\mathrm{L}$, control feed $+3 \%$ extruded linseed; $\mathrm{LO}$, control feed $+3 \%$ extruded linseed $+0.6 \%$ oregano 2 SEM, standard error of means. ${ }^{3} \mathrm{BW}$, body weight.

\subsection{Carcass Traits}

The slaughter weight, the hot and cold carcass dressing, and the right half carcass weight did not differ between the dietary treatments (Table 2). These results confirmed that extruded linseed can be a valid ingredient in the diet with no adverse effect on kids' performance compared to the control diet $[11,20]$. The $\mathrm{L}+\mathrm{O}$ groups showed heavier shoulders than the $\mathrm{C}$ group $(p=0.041)$ and lighter briskets than the Lroup $(p=0.046)$. These difference in carcasses were very small and were characterized by a high standard error of means, so they could be not attributed to the different feeding.

Table 2. Effect of diet on carcass traits.

\begin{tabular}{|c|c|c|c|c|c|}
\hline & \multicolumn{3}{|c|}{$\operatorname{Diet}^{1}$} & \multirow{2}{*}{ SEM } & \multirow{2}{*}{$p$-Value } \\
\hline & $\mathrm{C}$ & L & $\mathrm{L}+\mathrm{O}$ & & \\
\hline Final body weight (kg) & 11.70 & 12.28 & 12.56 & 2.211 & 0.55 \\
\hline Slaughter weight $(\mathrm{kg})$ & 10.37 & 12.20 & 11.42 & 1.816 & 0.64 \\
\hline Skin $(\%)^{2}$ & 7.31 & 8.19 & 7.88 & 0.867 & 0.74 \\
\hline Hot carcass dressing (\%) ${ }^{2}$ & 68.87 & 69.96 & 67.07 & 2.146 & 0.46 \\
\hline Cold carcass dressing $(\%)^{2}$ & 66.35 & 66.04 & 64.67 & 2.211 & 0.59 \\
\hline Carcass weight $(\mathrm{kg})$ & 6.42 & 6.64 & 6.68 & 1.096 & 0.42 \\
\hline \multicolumn{6}{|l|}{ Meat cuts $(\%)^{3}$} \\
\hline Neck & 6.50 & 6.72 & 6.93 & 0.413 & 0.25 \\
\hline Shoulder & $17.00^{b}$ & $17.26^{a b}$ & $17.62^{\mathrm{a}}$ & 0.520 & 0.04 \\
\hline Leg & 24.15 & 21.89 & 24.48 & 0.662 & 0.33 \\
\hline Steaks & 11.74 & 12.00 & 11.74 & 0.476 & 0.13 \\
\hline Abdominal region & 3.98 & 3.75 & 3.64 & 0.409 & 0.21 \\
\hline Loin & 5.34 & 5.00 & 5.30 & 0.239 & 0.19 \\
\hline Brisket & $6.97^{a b}$ & $7.10^{a}$ & $6.01^{b}$ & 0.500 & 0.046 \\
\hline Offal & 8.74 & 8.60 & 7.83 & 0.952 & 0.18 \\
\hline
\end{tabular}

${ }^{1} \mathrm{C}$, control feed; $\mathrm{L}$, control feed $+3 \%$ extruded linseed; $\mathrm{LO}$, control feed $+3 \%$ extruded linseed $+0.6 \%$ oregano

$2 \%$ on body weight; $3 \%$ on half carcass weight; means with different letters within each row differ significantly:

$\mathrm{a}, \mathrm{b}: p<0.05$. 
Linseed and oregano integration influenced the dissection data of leg and loin of kids (Table 3). In the dissection of leg, the $\mathrm{L}+\mathrm{O}$ kids showed the significant lowest percentage of dissectible fat $(p=0.002)$ and a higher percentage of bone $(p=0.035)$ than the L group. Additionally, in the dissection of loin, the $\mathrm{L}+\mathrm{O}$ group revealed a lower percentage of dissectible fat $(p=0.047)$ than the $L$ group. Lower percentage of fat in loin and leg were observed on lambs fed with linseed and oregano in the previous study presented by Scarpa et al. [12]. Other studies evaluating different natural dietary supplements have shown variable results concerning carcass traits, for example, Guzman et al. in their study on kids of the Payoya breed showed a significative influence of feed on shoulder dissection [21].

Table 3. Dissection data (\% on cut weight) of leg and loin of kids.

\begin{tabular}{cccccc}
\hline & \multicolumn{3}{c}{ Diet $^{\mathbf{1}}$} & \multirow{2}{*}{ SEM } & $p$-Value \\
\cline { 2 - 4 } & C & L & L + O & & \\
\hline Leg (kg) & 0.34 & 0.37 & 0.37 & 0.070 & 0.35 \\
Lean (\%) & 41.68 & 43.63 & 40.06 & 4.862 & 0.38 \\
Dissectible fat (\%) & $10.92^{\mathrm{A}}$ & $9.90^{\mathrm{a}}$ & $6.75^{\mathrm{Bb}}$ & 2.132 & 0.002 \\
Bone (\%) & $47.40^{\mathrm{ab}}$ & $46.47^{\mathrm{b}}$ & $53.19^{\mathrm{a}}$ & 4.746 & 0.04 \\
Loin (kg) & 1.46 & 1.80 & 1.56 & 0.303 & 0.29 \\
Lean (\%) & 63.20 & 64.15 & 62.88 & 2.447 & 0.35 \\
Dissectible fat (\%) & $6.31^{\mathrm{ab}}$ & $7.73^{\mathrm{a}}$ & $4.82^{\mathrm{b}}$ & 2.083 & 0.047 \\
Bone (\%) & 30.49 & 28.12 & 32.30 & 3.240 & 0.66 \\
\hline
\end{tabular}

${ }^{1} \mathrm{C}$, control feed; $\mathrm{L}$, control feed $+3 \%$ extruded linseed; $\mathrm{LO}$, control feed $+3 \%$ extruded linseed $+0.6 \%$ oregano. Means with different letters within each row differ significantly: ${ }^{\mathrm{a}, \mathrm{b}}: p<0.05{ }^{\mathrm{A}}{ }^{\mathrm{A}} \mathrm{B}: p<0.01$.

\subsection{Longissimus Lumborum Muscle Physical Characteristics}

Table 4 shows the Longissimus lumborum muscle physical characteristics. Dietary treatment influenced the $\mathrm{pH}$ value both at the $1 \mathrm{st} \mathrm{h}$ and at the 24th h post mortem. The $\mathrm{L}+\mathrm{O}$ Longissimus lumborum (Ll) showed the highest $\mathrm{pH}_{1}$ value compared to the $\mathrm{C}$ group $(p=0.027)$ and the lowest $\mathrm{pH}_{24}$ value $(p=0.009)$. According to the consulted literature, there is no clear effect of oregano integration on the $\mathrm{pH}$ of the meat; Simitzis et al. [22] showed that muscle $\mathrm{pH}$ increased after dietary oregano essential oil incorporation in female sheep. Instead, Kirkpinar et al. [23] on broiler meat and Simitzis et al. [24,25] on pig meat illustrated no significant differences in $\mathrm{pH} 45$ and $\mathrm{pH} 24$.

Table 4. Longissimus lumborum muscle physical characteristics.

\begin{tabular}{|c|c|c|c|c|c|}
\hline & \multicolumn{3}{|c|}{ Diet $^{1}$} & \multirow{2}{*}{ SEM } & \multirow{2}{*}{$p$-Value } \\
\hline & $\mathrm{C}$ & L & $\mathrm{L}+\mathrm{O}$ & & \\
\hline $\mathrm{pH}_{1} \#$ & $6.55^{b}$ & $6.65^{\mathrm{ab}}$ & $6.76^{\mathrm{a}}$ & 0.116 & 0.03 \\
\hline $\mathrm{pH}_{24} \#$ & $5.61^{\mathrm{a}}$ & $5.73^{\mathrm{A}}$ & $5.34^{\mathrm{Bb}}$ & 0.117 & 0.009 \\
\hline \multicolumn{6}{|l|}{3 day } \\
\hline $\mathrm{L}^{*}$ & 45.65 & 46.56 & 46.23 & 2.480 & 0.59 \\
\hline$a^{*}$ & 5.36 & 5.60 & 5.04 & 0.807 & 0.41 \\
\hline$b^{*}$ & 10.50 & 11.07 & 10.98 & 0.684 & 0.38 \\
\hline WBS, $\mathrm{kg} / \mathrm{cm}^{2}$ & 44.30 & 43.02 & 49.00 & 13.52 & 0.87 \\
\hline T-BARS (mg MDA/kg meat) & $0.398^{\mathrm{A}}$ & $0.434^{\mathrm{A}}$ & $0.247^{\mathrm{B}}$ & 0.122 & 0.004 \\
\hline \multicolumn{6}{|l|}{10 day } \\
\hline$L^{*}$ & 43.32 & 44.84 & 45.28 & 2.827 & 0.90 \\
\hline$a^{*}$ & 6.39 & 6.49 & 5.66 & 1.100 & 0.74 \\
\hline$b^{*}$ & 10.96 & 11.60 & 10.96 & 0.701 & 0.16 \\
\hline WBS, $\mathrm{kg} / \mathrm{cm}^{2}$ & 41.36 & 42.14 & 47.92 & 10.58 & 0.49 \\
\hline T-BARS (mg MDA/kg meat) & $0.417^{\mathrm{AB}}$ & $0.645^{\mathrm{A}}$ & $0.298^{B}$ & 0.278 & 0.006 \\
\hline
\end{tabular}

${ }^{1} \mathrm{C}$, control feed; $\mathrm{L}$, control feed $+3 \%$ extruded linseed; $\mathrm{LO}$, control feed $+3 \%$ extruded linseed $+0.6 \%$ oregano ${ }^{\#} \mathrm{pH}_{1}$ at $1 \mathrm{~h}$ post-mortem; ${ }^{\#} \mathrm{pH}_{24}$ at $24 \mathrm{~h}$ post-mortem; $\mathrm{L}^{*}$, Lightness; $\mathrm{a}^{*}$, redness; $\mathrm{b}^{*}$ yellowness; means with different letters within each row differ significantly: ${ }^{\mathrm{a}, \mathrm{b}}: p<0.05$; ${ }^{\mathrm{A}}, \mathrm{B}: p<0.01$. 
Colorimetric indices of $\mathrm{Ll}$ at $3 \mathrm{~d}$ and $9 \mathrm{~d}$ were not influenced by the diet. Our results are similar to those of other authors that studied the linseed and oregano effects on Garganica kids [14] and the supplementation of polyphenols on meat quality in Saanen kids [26], in which the colorimetric indices of $\mathrm{Ll}$ did not show feed influence.

In our study, dietary supplementation did not influence the WBS of Ll at $2 \mathrm{~d}$ and $9 \mathrm{~d}$ of ageing, whereas in other studies, diet did not show the influence on WBS of Ll of suckling kids [21,27]. Liotta et al. [28] highlighted a significant difference in WBS value on Messinese kids meat reared in a semi-extensive system; instead, Rotondi et al. [11] on Garganica kids showed a significant influence of linseed and oregano feed on WBS of fresh Ll.

The shelf life and acceptability of muscle foods can be increased by using nutritional strategy to improve the oxidative stability of animal products. The antioxidant compounds are incorporated in cell membranes, protecting them against oxidation and increasing meat stability $[29,30]$. In our study, the T-BARS values (mg of malondialdehyde-MDA/ $\mathrm{kg}$ meat) at $3 \mathrm{~d}$ were similar for Linseed and Control group, and their T-BARS value were higher than the L + O group ( $p=0.004)$; also, similar T-BARS value were described on Garganica kids [11]. A study on the addition of olive leaf (OL) extract in fattening Mahabadi male kids showed, as OL reduced TBARS in raw meat kids, with the same effect for oregano [31]. At 9th day of ageing, dietary treatment influenced the T-BARS value for the L group, which showed a higher value than the $\mathrm{L}+\mathrm{O}$ group. This result can be explained by the use of linseed, which makes the meat easier to oxidize [32] and the use of oregano for its antioxidant activity [10]. The acceptable MDA threshold content in the meat, for the sensory detection of rancid or anomalous flavors that make meat unacceptable for the consumers, is $1 \mathrm{mg} \mathrm{MDA} / \mathrm{kg}$ [33]. However, the MDA contents of kids fed with experimental diets were under this threshold.

\subsection{Chemical Composition of Longissimus Lumborum Muscle of Kids}

The chemical composition data of the Longissimus lumborum are shown in Table 5. The moisture content was higher $(p=0.001)$ in the $\mathrm{L}+\mathrm{O}$ group than in $\mathrm{L}$ group, and the same result was shown by [11]. Moreover, the L group showed the higher percentage of protein $(p=0.038)$ and lipid $(p=0.04)$ than the $C$ group; this difference is in line with the carcass fatness, where kids of L group showed the higher value of lean and fat in leg and loin cuts. Ash proportion was not influenced by the diet treatment, as the results showed by [34]. There is a little amount of data available about the influence of oregano on the chemical composition of kids or lambs. However, according to other authors, the group LO showed the lowest value of other extract in kids' meat [11], whereas linseed and oregano did not influence the chemical composition of lambs' meat [12] as well as for Grigia di Potenza kids' meat [20].

Table 5. Longissimus lumborum muscle chemical composition (\%).

\begin{tabular}{|c|c|c|c|c|c|}
\hline & \multicolumn{3}{|c|}{ Diet $^{1}$} & \multirow{2}{*}{ SEM } & \multirow{2}{*}{$p$-Value } \\
\hline & C & $\mathbf{L}$ & $\mathrm{L}+\mathrm{O}$ & & \\
\hline Moisture & $76.96^{\mathrm{AB}}$ & $75.86^{\mathrm{B}}$ & $77.56^{\mathrm{A}}$ & 0.350 & 0.001 \\
\hline Protein & $19.75^{b}$ & $20.11^{a}$ & $19.92^{a b}$ & 0.241 & 0.04 \\
\hline Lipid & $1.39^{\mathrm{B}}$ & $2.15^{\mathrm{A}}$ & $1.88^{\mathrm{AB}}$ & 0.249 & 0.004 \\
\hline Ash & 1.14 & 1.27 & 1.15 & 0.122 & 0.21 \\
\hline
\end{tabular}

${ }^{1} \mathrm{C}$, control feed; $\mathrm{L}$, control feed $+3 \%$ extruded linseed; $\mathrm{LO}$, control feed $+3 \%$ extruded linseed $+0.6 \%$ oregano. Means with different letters within each row differ significantly: ${ }^{\mathrm{a}, \mathrm{b}}: p<0.05 ;{ }^{\mathrm{A}}, \mathrm{B}: p<0.01$.

\subsection{Longissimus Lumborum Muscle Fatty Acid Composition}

In Table 6, the fatty acid composition of kids' Longissimus lumborum is shown. The dietary treatment influenced the percentage of saturated fatty acid (SFA); therefore, the $\mathrm{L}+\mathrm{O}$ group showed a lower value of SFA than the C group $(p=0.037)$ and the lowest value of C10:0 ( $p=0.007)$, results very similar to those of Scarpa et al. [12]. In addition, monounsaturated fatty acid (MUFA) were influenced by diet, and the $\mathrm{L}$ and the $\mathrm{L}+\mathrm{O}$ 
group showed the highest values of C18:1 $\mathrm{n} 9$ cis $(p=0.005)$ and total MUFA $(p=0.032)$, which are presented in higher quantity in linseed. C18:2 $\mathrm{n} 6$ was higher $(p=0.036)$ in the $\mathrm{C}$ group than the group fed with linseed. Contrarily, C18:3 n 3 was the lowest in the $\mathrm{C}$ group $(p=0.004)$. The $\mathrm{L}+\mathrm{O}$ group showed the highest value of $\mathrm{C} 20: 3 \mathrm{n} 3(p=0.001)$ and $\mathrm{C} 20: 4$ n6 $(p=0.006)$ compared with $C$ and L group, probably due to the antioxidant capacity of oregano. $\mathrm{L}+\mathrm{O}$ value of $\mathrm{C} 22: 6 \mathrm{n} 3$ and total UFA were higher $(p=0.001)$ than the $\mathrm{C}$ group. These differences led the $\mathrm{L}+\mathrm{O}$ group to obtain a higher value of total PUFA $(p=0.039)$ than the L group. The $C$ group showed the highest value of $n-6$ PUFA $(p=0.007)$ and the lowest value of $n-3$ PUFA $(p=0.004)$, values that, obviously, bring in the highest value of $\mathrm{n}-6 / \mathrm{n}-3$ ratio. Instead, the groups fed with linseed showed values of $n-6 / n-3$ ratio very near to 4 , the recommended value to prevent or modulate certain human diseases [35].

Table 6. Longissimus lumborum muscle fatty acid composition (\% $100 \mathrm{~g}$ FA methyl esters).

\begin{tabular}{|c|c|c|c|c|c|}
\hline & \multicolumn{3}{|c|}{ Diet $^{1}$} & \multirow{2}{*}{ SEM } & \multirow{2}{*}{$p$-Value } \\
\hline & $\mathrm{C}$ & $\mathbf{L}$ & $\mathbf{L}+\mathrm{O}$ & & \\
\hline Total Fatty acids (g/100 g muscle) & 1.21 & 1.72 & 1.56 & 0.29 & 0.25 \\
\hline C10:0 (capric) & 0.29 & 0.35 & 0.37 & 0.902 & 0.36 \\
\hline C12:0 (lauric) & $1.20^{\mathrm{a}}$ & $0.85^{b}$ & $0.99 \mathrm{ab}$ & 0.286 & 0.04 \\
\hline C14:0 (myristic) & $2.82^{\mathrm{A}}$ & $1.85^{\mathrm{B}}$ & $1.45^{\mathrm{B}}$ & 0.587 & 0.007 \\
\hline C15:0 & 0.23 & 0.18 & 0.40 & 0.438 & 0.048 \\
\hline C16:0 (palmitic) & 26.37 & 25.20 & 24.35 & 2.039 & 0.75 \\
\hline $\mathrm{C} 17: 0$ & 0.87 & 0.98 & 0.97 & 0.223 & 0.69 \\
\hline C18:0 (stearic) & 15.74 & 16.13 & 16.12 & 2.024 & 0.67 \\
\hline C20:0 & 0.71 & 0.74 & 0.68 & 0.513 & 0.81 \\
\hline$\sum$ SFA & $48.85^{a}$ & $46.84^{a b}$ & $45.95^{b}$ & 2.066 & 0.04 \\
\hline C14:1 & 0.33 & 0.66 & 0.65 & 0.580 & 0.48 \\
\hline C15:1 & 0.10 & 0.14 & 0.43 & 0.338 & 0.77 \\
\hline C16:1 n7 (palmitoleic) & 1.73 & 1.48 & 1.70 & 0.441 & 0.34 \\
\hline C17:1 & 0.41 & 0.48 & 0.33 & 0.180 & 0.42 \\
\hline C18:1 n9 trans (elaidic) & 2.33 & 2.33 & 2.17 & 0.506 & 0.30 \\
\hline C18:1 n9 cis (oleic) & $36.09 \mathrm{Bb}$ & $38.39^{\mathrm{A}}$ & $37.81^{\mathrm{a}}$ & 1.630 & 0.005 \\
\hline$\sum$ MUFA & $42.45^{b}$ & $45.19^{\mathrm{a}}$ & $45.24^{\mathrm{a}}$ & 2.110 & 0.03 \\
\hline C18:2 n6 (linoleic) & $6.58^{a}$ & $5.41^{\mathrm{b}}$ & $5.97^{\mathrm{ab}}$ & 0.626 & 0.04 \\
\hline CLA c9, t11 & 0.16 & 0.17 & 0.11 & 0.116 & 0.23 \\
\hline CLA t10, c12 & 0.17 & 0.10 & 0.13 & 0.080 & 0.33 \\
\hline C18:3 n6 & 0.57 & 0.45 & 0.54 & 0.312 & 0.15 \\
\hline C18:3 n3 ( $\alpha$-linolenic) & $0.36^{\mathrm{Bb}}$ & $0.73^{\mathrm{A}}$ & $0.59^{a}$ & 0.159 & 0.004 \\
\hline $\mathrm{C} 20: 3 \mathrm{n} 3$ & $0.17^{\mathrm{B}}$ & $0.25^{b}$ & $0.34^{\mathrm{Aa}}$ & 0.075 & 0.001 \\
\hline C20:4 n6 (arachidonic) & $0.14^{b}$ & $0.12^{\mathrm{B}}$ & $0.29^{\mathrm{Aa}}$ & 0.108 & 0.006 \\
\hline C20:5 n3 (eicosapentaenoic) & 0.19 & 0.22 & 0.26 & 0.074 & 0.12 \\
\hline C22:5 n3 (docosapentaenoic) & 0.06 & 0.08 & 0.09 & 0.047 & 0.06 \\
\hline C22:6 n3 (docosaesaenoico) & $0.18^{\mathrm{B}}$ & $0.25^{\mathrm{AB}}$ & $0.33^{\mathrm{A}}$ & 0.086 & 0.001 \\
\hline$\sum$ PUFA & $8.69 \mathrm{ab}$ & $7.94^{b}$ & $8.80^{\mathrm{a}}$ & 0.823 & 0.04 \\
\hline$\sum$ UFA & $51.15^{\mathrm{b}}$ & $53.16^{\mathrm{ab}}$ & $54.05^{\mathrm{a}}$ & 2.066 & 0.02 \\
\hline Total n-6 & $7.39^{\mathrm{A}}$ & $6.05^{\mathrm{Bb}}$ & $6.89^{a}$ & 0.714 & 0.007 \\
\hline Total n-3 & $0.91^{\mathrm{B}}$ & $1.47^{\mathrm{A}}$ & $1.52^{\mathrm{A}}$ & 0.163 & 0.004 \\
\hline$n-6 / n-3$ & $8.60^{\mathrm{A}}$ & $4.26^{\mathrm{B}}$ & $4.57^{\mathrm{B}}$ & 1.113 & 0.008 \\
\hline A.I. & $0.77^{\mathrm{A}}$ & $0.64^{\mathrm{B}}$ & $0.60^{\mathrm{B}}$ & 0.091 & 0.002 \\
\hline T.I. & $1.61^{\mathrm{Aa}}$ & $1.42^{b}$ & $1.36^{\mathrm{B}}$ & 0.142 & 0.004 \\
\hline
\end{tabular}

${ }^{1} \mathrm{C}$, control feed; $\mathrm{L}$, control feed $+3 \%$ extruded linseed; $\mathrm{LO}$, control feed $+3 \%$ extruded linseed $+0.6 \%$ oregano SFA, saturated fatty acids; MUFA, monounsaturated fatty acids; PUFA, polyunsaturated fatty acids; UFA, unsaturated fatty acids (sum of MUFA and PUFA); A.I., atherogenic index; T.I., thrombogenic index. Means with different letters within each row differ significantly: ${ }^{\mathrm{a}, \mathrm{b}}:(p<0.05){ }^{\mathrm{A}, \mathrm{B}}:(p<0.01)$.

Study on the influence of heated linseed (HLS) on the fatty acid of rumen concentration showed that inclusion of HLS in the diet increased the rumen concentration of $\mathrm{C} 18: 3 \mathrm{n} 3$ and $n-3$ PUFA and decreased the concentration of n- 6 PUFA, therefore decreasing the n- $6 / n-3$ 
ratio [35]. Clearly, the supplementation of HLS increased the biohydrogenation of $n-6$ PUFA but decreased the biohydrogenation of n-3 PUFA, with the outcome resulting in a higher concentration of C18:3 n3 and n-3 PUFA in subcutaneous adipose tissue [36] and in intramuscular fat [11] of kids. The same diet used with lambs by Scarpa et al. [12] showed a higher value of $n-3$ PUFA that positively influenced the $n-6 / n-3$ ratio.

Atherogenicity and of thrombogenicity indices are values that suggest how fatty acids present in foods affect the human cardiovascular health: the smaller the value, the healthier the food [16]. In our trial, control group meat showed a slightly higher atherogenic $(p=0.002)$ and thrombogenic $(p=0.004)$ index compared to the other two groups.

\section{Conclusions}

The trial highlighted that the use of feed with added $\mathrm{L}+\mathrm{O}$ did not influence growth performance of kids. This diet affected the percentage of fat in the loin and the leg, the lipid oxidation, the chemical composition of the meat, and its FA profile.

The healthy and beneficial effect of linseed in the diet is observed in meat with the lower value of $n-6 / n-3$ ratio and atherogenic and thrombogenic indices.

As we hypothesized, the meat of the $\mathrm{L}$ group, because it is fatter, is easier to oxidize, whereas the use of oregano and its antioxidant activity made the fresh and ageing $\mathrm{L}+\mathrm{O}$ meat the lowest in MDA as well as less oxidized.

Author Contributions: Conceptualization, M.R.; G.D.M., and S.T.; methodology, F.V. and S.C.; formal analysis and investigation, F.V.; data curation, S.T.; writing-original draft preparation, writingreview and editing, S.T. and M.R.; visualization, S.T.; supervision, M.R. All authors have read and agreed to the published version of the manuscript.

Funding: The present research was part of the project founded and supported by the Basilicata Region, Italy "VAL.BI.OVI.CAP.—PSR Basilicata 2014-2020-Misura 10—Sottomisura 10.2—Sostegno per la conservazione, l'uso e lo sviluppo sostenibili delle risorse genetiche in agricoltura".

Institutional Review Board Statement: Ethical review and approval were waived for this study due to animals were cared for and handled in compliance with the EU legislation on animal welfare regulations (Directive 2010/63/EU, which updates and replaces the 1986 Directive 86/609/EEC on the protection of animals used for scientific purposes) and following the University research polices.

Informed Consent Statement: Not applicable.

Data Availability Statement: All data generated or analyzed during this study are included in this article.

Acknowledgments: The authors would like to thank the technicians Massimo Lacitignola, Nicolò Devito, and Domenico Gerardi for their laboratory assistance.

Conflicts of Interest: The authors declare no conflict of interest.

\section{References}

1. De Marzo, D.; Nicastro, F. The Jonica and Maltese Goat Breeds Reared in Different Regions of Italy. In Sustainable Goat Production in Adverse Environments: Volume II; Simões, J., Gutiérrez, C., Eds.; Springer: Cham, Switzerland, 2017. [CrossRef]

2. Webb, E.C.; Casey, N.H.; Simela, L. Goat meat quality. Small Rumin. Res. 2005, 60, 153-166. [CrossRef]

3. Borgogno, M.; Corazzin, M.; Saccà, E.; Bovolenta, S.; Piasentier, E. Influence of familiarity with goat meat on liking and preference for capretto and chevon. Meat Sci. 2015, 106, 69-77. [CrossRef] [PubMed]

4. Dhanda, J.S.; Taylor, D.G.; McCosker, J.E.; Murray, P.J. The influence of goat genotype on the production of capretto and chevon carcass. 1. Growth and carcass characteristics. Meat Sci. 1999, 52, 355-361. [CrossRef]

5. Todaro, M.; Corrao, A.; Alicara, M.L.; Schinelli, R.; Giaccone, P.; Priolo, A. Effects of litter size and sex on meat quality traits of kid meat. Small Rumin. Res. 2004, 54, 191-196. [CrossRef]

6. Wahle, K.W.J.; Heys, S.D.; Rotondo, D. Conjugated linoleic acids: Are they beneficial or detrimental to health? Prog. Lipid Res. 2004, 43, 553-587. [CrossRef] [PubMed]

7. Colonna, M.A.; Rotondi, P.; Selvaggi, M.; Jambrenghi, A.C.; Ragni, M.; Tarricone, S. Sustainable Rearing for Kid Meat Production in Southern Italy Marginal Areas: A Comparison among Three Genotypes. Sustainability 2020, 12, 6922. [CrossRef]

8. Wood, J.; Richardson, R.; Nute, G.; Fisher, A.; Campo, M.; Kasapidou, E.; Sheard, P.; Enser, M. Effects of fatty acids on meat quality: A review. Meat Sci. 2004, 66, 21-32. [CrossRef] 
9. Cosentino, C.; Colonna, M.; Musto, M.; Dimotta, A.; Freschi, P.; Tarricone, S.; Ragni, M.; Paolino, R. Effects of dietary supplementation with extruded linseed and oregano in autochthonous goat breeds on the fatty acid profile of milk and quality of Padraccio cheese. J. Dairy Sci. 2021, 104, 1445-1453. [CrossRef]

10. Pérez-Rosés, R.; Risco, E.; Vila, R.; Peñalver, P.; Cañigueral, S. Biological and nonbiological antioxidant activity of some essential oils. J. Agric. Food Chem. 2016, 64, 4716-4724. [CrossRef]

11. Rotondi, P.; Colonna, M.A.; Marsico, G.; Giannico, F.; Ragni, M.; Facciolongo, A.M. Dietary Supplementation with Oregano and Linseed in Garganica Suckling Kids: Effects on Growth Performances and Meat Quality. Pak. J. Zool. 2018, 50, 1421-1433. [CrossRef]

12. Scarpa, G.; Tarricone, S.; Ragni, M. Carcass Composition, Meat Quality and Sensory Quality of Gentile di Puglia Light Lambs: Effects of Dietary Supplementation with Oregano and Linseed. Animals 2021, 11, 607. [CrossRef] [PubMed]

13. National Research Council. Nutrient Requirements of Small Ruminants: Sheep, Goats, Cervids and New World Camelids; The National Academy Press: Washington, DC, USA, 2007.

14. Association of Official Agricultural Chemistry. Official Methods of Analysis of the AOAC, 17th ed.; Association of Official Analytical Chemists: Arlington, VA, USA, 2000.

15. Lestingi, A.; Colonna, M.; Marsico, G.; Tarricone, S.; Facciolongo, A. Effects of legume seeds and processing treatment on growth, carcass traits and blood constituents of fattening lambs. S. Afr. J. Anim. Sci. 2019, 49, 799-809. [CrossRef]

16. Ulbricht, T.L.V.; Southgate, D.A.T. Coronary heart disease: Seven dietary factors. Lancet 1991, 338, 985-992. [CrossRef]

17. SAS. SAS/STAT 9.13 User's Guide; Statistical Analysis System Institute: Cary, NC, USA, 2004.

18. Wang, X.; Martin, G.B.; Wen, Q.; Liu, S.; Zhang, J.; Yu, Y.; Shi, B.; Guo, X.; Zhao, Y.; Yan, S. Linseed oil and heated linseed grain supplements have different effects on rumen bacterial community structures and fatty acid profiles in cashmere kids. J. Anim. Sci. 2019, 97, 2099-2113. [CrossRef]

19. Liu, S.; Wang, X.; Li, Y.; Shi, B.; Guo, X.; Zhao, Y.; Yan, S. Flaxseed Oil and Heated Flaxseed Supplements Have Different Effects on Lipid Deposition and Ileal Microbiota in Albas Cashmere Goats. Animals 2021, 11, 790. [CrossRef]

20. Tarricone, S.; Giannico, F.; Ragni, M.; Colonna, M.A.; Rotondi, P.; Cosentino, C.; Tufarelli, V.; Laudadio, V. Effects of dietary extruded linseed (Linum usitatissimum L.) and oregano (Origanum vulgare) on growth traits, carcass composition and meat quality of Grigia di Potenza suckling kids. Intern. J. Agric. Biol. 2021, 25, 1153-1160. [CrossRef]

21. Guzman, J.L.; de la Vega, F.; Zarazaga, L.A.; Arguello, A.; Delgrado-Pertinez, M. Carcass characteristics and meat quality of conventionally and organically reared suckling dairy goat kids of the Payoya breed. Ann. Anim. Sci. 2019, 19, 1143-1159. [CrossRef]

22. Simitzisa, P.E.; Deligeorgisa, S.G.; Bizelisa, J.A.; Dardamania, A.; Theodosioua, I.; Fegeros, K. Effect of dietary oregano oil supplementation on lamb meat characteristics. Meat Sci. 2008, 79, 217-223. [CrossRef]

23. Kirkpinar, F.; Ünlü, H.B.; Serdaroğlu, M.; Turp, G.Y. Effects of dietary oregano and garlic essential oils on carcass characteristics, meat composition, colour, $\mathrm{pH}$ and sensory quality of broiler meat. Br. Poult. Sci. 2014, 55, 157-166. [CrossRef]

24. Simitzis, P.E.; Symeon, G.K.; Charismiadou, M.A.; Bizelis, J.A.; Deligeorgis, S.G. The effects of dietary oregano oil supplementation on pig meat characteristics. Meat Sci. 2010, 84, 670-676. [CrossRef]

25. Tarricone, S.; Colonna, M.; Giannico, F.; Ragni, M.; Lestingi, A.; Facciolongo, A. Effect of an extruded linseed diet on meat quality traits in Nero Lucano pigs. S. Afr. J. Anim. Sci. 2020, 49, 1093-1103. [CrossRef]

26. Cimmino, R.; Barone, C.M.A.; Claps, S.; Varricchio, E.; Rufrano, D.; Caroprese, M.; Albenzio, M.; De Palo, P.; Campanile, G.; Neglia, G. Effects of dietary supplementation with polyphenols on meat quality in Saanen goat kids. BMC Vet. Res. 2018, 14, 181. [CrossRef]

27. De souza, P.P.S.; Barros Gomes, H.F.; Gonçalves, H.C.; Lima Meirelles, P.R.; Marques, R.O.; Prestes Brito, E.; de Oliveira, G.M.; Corrêa, H.L. Effects of feeding systems and breed group on carcass characteristics and meat quality of feedlot goat kids. Semin. Ciências Agrárias 2018, 39, 1759-1774. [CrossRef]

28. Liotta, L.; Chiofalo, V.; Lo Presti, V.; Chiofalo, B. Effect of production system on growth performances and meat traits of suckling Messinese goat kids. Ital. J. Anim. Sci. 2020, 19, 245-252. [CrossRef]

29. Kerry, J.P.; Buckley, D.J.; Morrissey, P.A.; O'Sullivan, K.; Lynch, P.B. Endogenous and exogenous $\alpha$-tocopherol supplementation: Effects on lipid stability (TBARS) and warmed-over flavour (WOF) in porcine M. longissimus dorsi roasts held in aerobic and vacuum packs. Food Res. Int. 1998, 31, 211-216.

30. Surai, P.F. Polyphenol compounds in the chicken/animal diet: From the past to the future. J. Anim. Phys. Anim. Nutr. 2014, 98, 19-31. [CrossRef] [PubMed]

31. Hukerdi, Y.J.; Nasri, M.F.; Rashidi, L.; Ganjkhanlou, M.; Emami, A. Effects of dietary olive leaves on performance, carcass traits, meat stability and antioxidant status of fattening Mahabadi male kids. Meat Sci. 2019, 153, 2-8. [CrossRef]

32. Huang, X.; Ahn, D.U. Lipid oxidation and its implications to meat quality and human health. Food Sci. Biotechnol. 2019, 28, 1275-1285. [CrossRef] [PubMed]

33. Ripoll, G.; Joy, M.; Muñoz, F. Use of dietary vitamin E and selenium (Se) to increase the shelf life of modified atmosphere packaged light lamb meat. Meat Sci. 2011, 87, 88-93. [CrossRef]

34. Facciolongo, A.M.; De Marzo, D.; Ragni, M.; Lestingi, A.; Toteda, F. Use of alternative protein sources for finishing lambs. 2. Effects on chemical and physical characteristics and fatty acid composition of meat. Prog. Nutr. 2015, 17, 165-173. 
35. WHO/FAO (World Health Organization/Food and Agriculture Organization). Diet, Nutrition and the Prevention of Chronic Diseases; WHO Technical Report Series; WHO: Geneva, Switzerland, 2003.

36. Wang, X.; Martin, G.B.; Liu, S.L.; Shi, B.L.; Guo, X.Y.; Zhao, Y.L.; Yan, S.M. The mechanism through which dietary supplementation with heated linseed grain increases n-3 long-chain polyunsaturated fatty acid concentration in subcutaneous adipose tissue of cashmere kids. J. Anim. Sci. 2018, 97, 385-397. [CrossRef] [PubMed] 